\title{
Multi Layer Feed Forward Neural Network Knowledge Base to Future Stock Market Prediction
}

\author{
G.Sundar, K.Satyanarayana
}

\begin{abstract}
Stock price prediction is always a most challenging task. Artificial Neural Network prediction clears the stock price prediction challenge by forming the training set. By using the past information as the network input, one can predict the expected output of the network. In order to predict the expected result as the accurate we add multi-layer perceptron to the knowledge set we formed from the past historical data available in the nifty NSE and Sensex BSE. This paper proves that proposing the learning knowledge set using multilayer neural network will predict the accurate closing price of future stock in stock market.
\end{abstract}

Keywords: Artificial Neural Network (ANN), Knowledge set, Multilayer neural perceptron network, stock market.

\section{INTRODUCTION}

In stock market, the identification of expected loss and profit is used for buying or selling a stock. Always the person in the stock market tries to make preventive measure with the help of the parameter feature related to the stock price. Historical data like open price, high price and low-price are used to identify the behavior of stock. The usage of these historical details creates high degree of accuracy in the prediction in stock market. In this paper we will work with these historical features of stock price by using multilayer neural perceptron network to predict the closing price of the stock.

\section{A. Stock market}

Stock market offers the investors to a public sale to buy or sell the stocks. Stock market is also known as the exchanges of regular activities including insurance of shares. Stock market, stock trading and stock exchange are some of the terms used interchangeably. Investors need low rick in stock investment. The investors mostly use diversified investment which has lower risk. To get huge financial capital

Revised Manuscript Received on September 22, 2019.

G.Sundar, Research Scholar, Bharath University, Chennai, sundarganapathy66@gmail.com.

Dr.K.Satyanarayana, Research Supervisor, Bharath University, Chennai.Principal \& Prof, Dept. of Computer Science, Sindhi College, Chennai. companies are used to sell the stocks. Individuals are also use the stock market to gain returns and outpace of their investments. The investment occurs in stock market only if the investors believe that the economy is growing. If the investors think that the economy is unmoving or frozen then they are not invest in stock. Nowadays any one can possibly purchase the stock in online.

Stock market is acts as primary market as well as secondary markets. The company which offers their share for first time for selling or buying is known as primary market. The regular buying and selling of the listed shares of the company in the stock exchange is known as secondary market. Both the primary and secondary stock market performs the trading execution at a fair price to the mutual buyers and sellers. There are two free-float market weighted stock index known as NIFTY 50 and BSE SENSEX.

The NIFTY 50 index is National Stock Exchange of India's benchmark based stock market index for the Indian equality market. Full form the NIFTY is National Stock Exchange Fifty. It represents the weighted average of 50 Indian company stocks in 13 sectors. It is one of the two main stock indices used in India. The BSE SENSEX is the S\&P Bombay Stock Exchange Sensitive Index or simply the SENSEX. It includes 30 company stocks in 13 sectors. Some of the sectors are shipping, banking, automobile, financial services, telecommunication, oil \& gas, pharmaceuticals, metals, consumer goods, cement, information technology, metals, chemicals and media \& entertainment.

\section{B. Artificial Neural Network}

ANN has been applied in many different domains with success. ANN follows generalization ability on a learned base of examples. Several methods of ANN have been designed to explicit their knowledge in a symbolic form. ANN is used to form the basis of empirical learning. ANN has been proven to be equal or superior to empirical learning systems over a wide range of domains. Empirical learning means generalize specific theoretical knowledge about the problem domain. 
ANN used to make the assumptions about the functional dependencies between the input and output. ANN is a method of finding the relevant weights with the number of thresholds required for computation. The training of neural network is done by the investigation of the historical data. The training data selection is a critical task.

\section{STANDARD STOCK KNOWLEDGE SYSTEM}

Knowledge is a communication progression between the learner and the surroundings. The learner receives information from the surroundings, and processes the information to form knowledge. The learner uses this learned knowledge to help in making decisions and in solving problems. The performance of problem solving will feed back to the learner. This process occurs iteratively and continues until the knowledge gained. The surroundings serves as a stimulus to the learner, and the level and quality of information affect the strategy of learning. Generally, there are three main learning paradigms: supervised, semi-supervised, and unsupervised learning. The goal of the learning is to generate the regularities from the training set of input patterns. Among these three learning paradigms, although the level and quality of information from the environment vary, they share with one common learning strategy that learning comes passively from the environment.

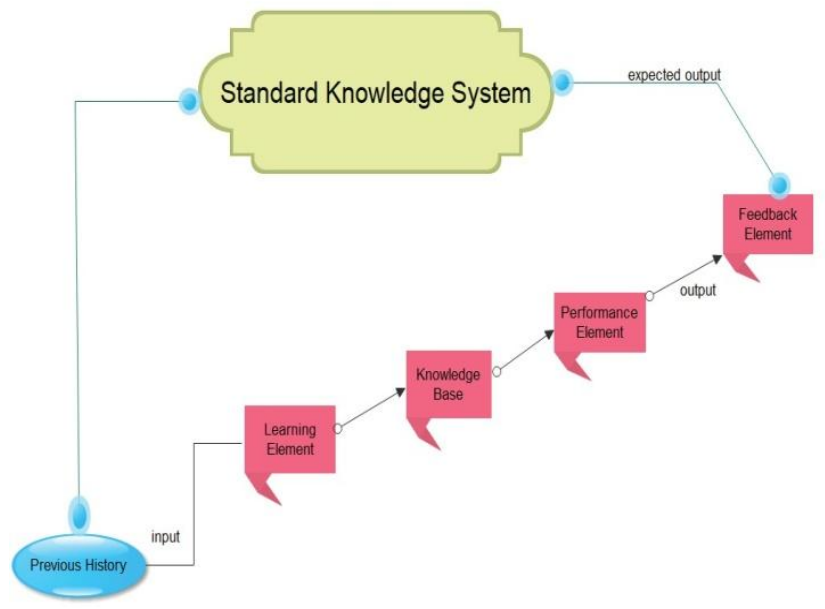

Diagram 1 Typical Standard Stock Knowledge System model

The above Diagram 1 shows a typical knowledge set model. The typical system model of standard stock knowledge consists of the five necessary elements. All these elements are used to form the expected output from the historical data. The standard stock knowledge elements are

- Learning element

- Knowledge Base

- Performance neuron element

- Feedback elements
- Standard knowledge system

\section{B. Learning Element}

It receives and processes the input obtained from past history. Learning technique is a process which is used for the making of learning element. It is also necessary for building the blocks of all Artificial Neural Network model based solution. It receives and processes the input obtained from past historical data. Learning method is used to form a new patterns or approaches which is entirely different from the existing methods. Using learning technique observations are formed from the past details of the system. This learning improves the knowledge defined by ANN technique. This is best in multi-layer perceptron class problems. The understanding of the problem is done by using this multi-layer function. Usually stock market problems are divided by fundamental analysis problems and technical analysis problems. Analysing of company's future profitability with the help of its business environment and financial performance is known as fundamental analysis. Identifying the trends of stock market with the help of understanding the statistical charts is known as technical analysis problems. The learning element in this paper includes the analysis of the historical data which focus on the technical analysis. The learning elements of stock market prediction are date, open, high, low, and close.

Multilayer neural networks are made up of three or more layers. This network has more than one hidden layer between the input nodes and output nodes. The structure is shown in the below diagram 2 .

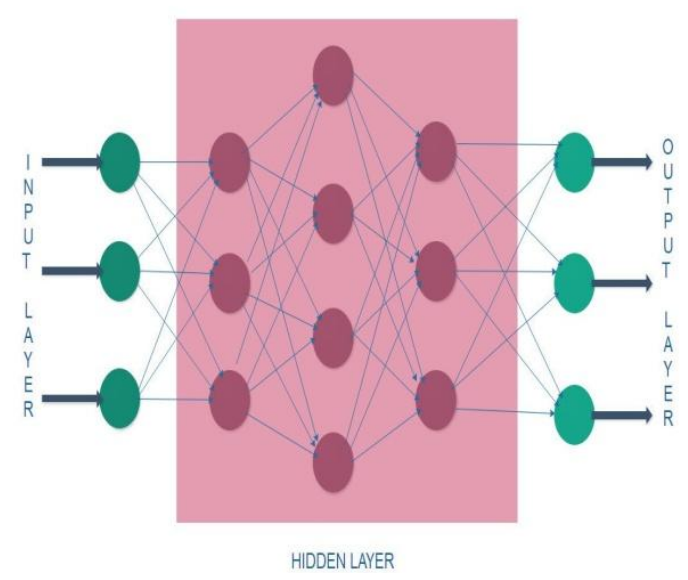

Diagram 2 Multi-layer neural networks

In MLNN signals are travelled in both directions. This network introduces loops. This method is also known as interactive network. This network also has 3 major groups of layers. Input layers hidden layers and output layers. Input layers are used to represent the data, which is to be fed into the network. The one hidden layer needs to represent the weights on 
the connections between input and weights and hidden layers. These may be more the one hidden layer depending upon the network. The final layer is output layer which is used to represent the output unit depend on weights given between hidden layers.

\section{Knowledge base}

This is similar to data base. It may contain some basic initial knowledge. It receives more knowledge which may be new and so be added as it or it may replace the existing knowledge. Knowledge is a set mainly used for forming a statement about the future prediction. In scientific work observations and evidences are used to form a quantitative statement about the knowledge set. In this paper knowledge base of stock market is obtained by using artificial neural network technique. Knowledge base is formed for grouping the label from raw historical data. This is also used to identify the patterns in the data like numeric, string, or vector. Neural network is used identify these grouping label to identify the input layers for prediction. These labeled data are used to form training data set. This knowledge base is used to maps the inputs to outputs. The knowledge base is formed by using multi-layer perceptron. The layers are made of various nodes. These nodes are used to combines the data with a set of coefficients known as input layers. All these input layers are used to form the activation function to determine the progress of the network to form the outcome known as knowledge base of classification. This is passed as the signals to neuron in order to activate the function used in the network. The depth of the multi-layer perceptron neural network defines the node layers through which the data pass in to the pattern identification process. Hierarchical structure is formed to abstract the increasing complexity to handle the high-dimensional data set passed through the activation function. Artificial neural network has multi-layer perceptron which is best for discovering the hidden structures within the historical data. Knowledge base is formed using pattern learning in stock historical data to extract necessary features like date, open price, close price, high price, low price and volume. By using neural networks one learns and recognizes the relation between certain necessary features and optimal outcome. Diagram 3 describes the basis for prediction used from the knowledge base set.

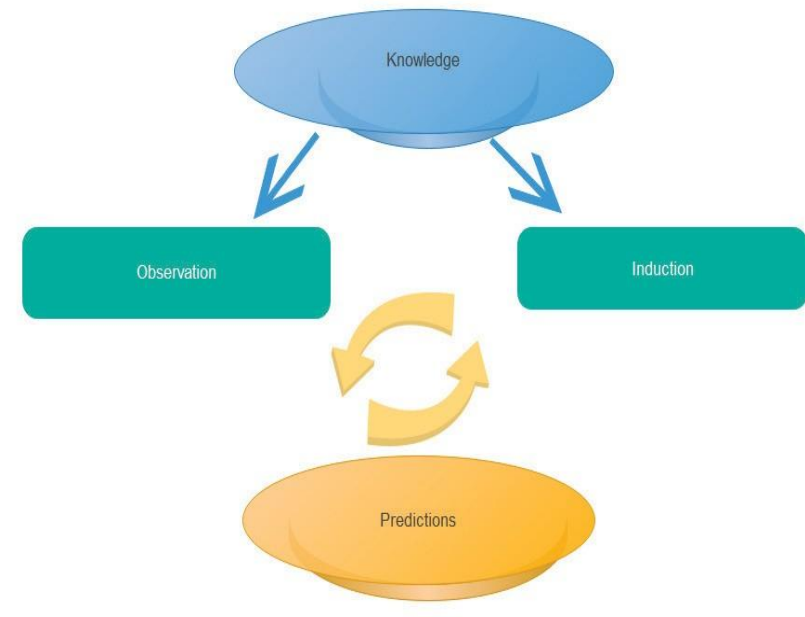

Diagram 3 General structure of Knowledge base The knowledge base is formed by using the independent learning elements with the corresponding related weights.

Here is the knowledge base of the neural network formed. ,$\ldots$ are the independent learning elements and ... are the weights related to the elements. In this stock prediction problem we have date as the independent learning elements.

\section{Performance element}

It uses the updated knowledge base to perform some tasks or solves some problems and produces the corresponding output. The performance element in our study is stock market. All patterns are depends on labeled datasets. Artificial neural network is used to learn the patterns between the labels and the data. The label which is used to generate the output of the data is used to train the neural network. The performance element is found by grouping of label in the data by detecting relationships between them. The predictive analysis is done to evaluate the performance element. The performance element of the future stock prediction is done by determining the closing price of a stock for the day. The closing price is also known as the target variable.

Generally the performance element is formed by generating neuron. The neuron generation is the beginning of the artificial neural network. It is the basic building block of brain. It is a simplified form of numerical processing unit. All neurons are inter-connected and operating in parallel. Each neuron takes input value from other neurons and transfers it as the function and sends it on to the next layer like cascading till it reach the output. ANN is developed to attempt to simulate human brain. The major key point of ANN is information processing. Neuron is helped to inter-connect the working of ANN. ANN is used to form pattern learning.

ANN 
performance is described using the Diagram 4.

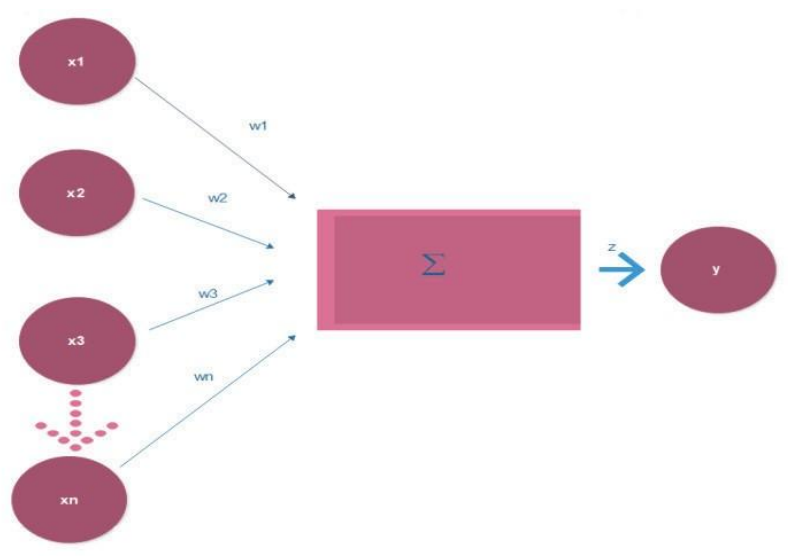

Diagram 4 Performance element of neural network

The closing price is predicted by using the moving average formula of multi-layer perceptron which uses the latest prediction of each data set. The data set is fragmented into train and validated set. In this paper we use last year data into fragmentation. Heuristics technique is used for processing the learning element. In the paper we form the learning element for the stock market prediction. The evaluation function for creating learning element for stock using heuristic function is denoted as " $\mathrm{Y}$ ". The performance element from the learning element is formed using the formula

$\mathrm{Y}=$

Where network are weights and are input attributes used in the function.Heuristic function is used for selecting best form the available set.

\section{E. Feedback element}

It has two inputs one from the learning system and another from standard system. The feedback system is used to determine what should be done in order to produce the correct output. In this paper a neural net is used to arrive with least error. The weights are collected and the start or end states are attempts to model data's relationship. Neural networks are always accepting the ignorance. The weights and biases are not known clearly in neural network. It is always starts with the presumption and makes the better presumptions in sequential manner as it learns from mistakes.

The feedback element assumption with the network input and weight is defined as assumption $=$ input $*$ weight

\section{F. Standard Knowledge System}

It is a trained person or a computer program that is able to produce the correct output. In order to check whether the system has learned well, the same input is given to the standard system. The outputs of the standard knowledge system and the performance element are given as input to the feedback element to form idealized system.

The sequence of the operation is repeated until the system gets desired perfection. The knowledge system is formed by using the activation function. The activation function determines the output node by fixing the inputs. The activation function is set at all the layer levels. Generally logistic regression function is used in the multi-layer perceptron neural network model knowledge system. This neural network includes many layers like input layers, hidden layers and output layers. Each of the output neural network nodes produces two possible outcomes in binary form known as 0 or 1 . The logistic regression function is used to the conversion of the continuous parameter value into the binary output.

\section{BUILDING THE MULTI-LAYER NEURAL NETWORK MODEL}

First import the data from the historical data to CSV (comma-separated value) file. The construction of stock prediction model using multi-layer neural network has inputs like, date, open price, high price and low price. The linear regression is used in the single-layer network formation. The simplest form of the linear regression is expressed as,

(3)

Where ' $\mathrm{Y}$ ' is the estimated output, $\mathrm{X}$ is the input, $\mathrm{m}$ is the slope and $b$ is the intercept of the vertical axis. This is extended up to multiple linear regressions, which has many input variables to produce one output. The output form is expressed as,

(4)

The above equation is used to form the multiple linear regressions at every node of the multi-layer neural network. In this network the previous layer is again pooled with the input from every other node.

In general the multi-layer neural network is represented as using the neurons in a hidden layer in feature detectors. This is used to detect feature in historical input data. It is used to combine all input to the output. The common rule is

\section{$\mathrm{Y}=\sum$ (weight $*$ input $)+$ bias $\quad$ (5)}

This hybrid proportion with respect to the subsequent layer combinations are used to the error. The training set is used to form feature related to prediction. This is used to specify of modify weights between nodes. There is no specific way or method to choose bias value. It is randomly or chosen by the designer. Training set is formed by historical dataset available 
about stock. Then the network is given as input and processed to produce resultant output. In training set a detailed study of past data performance value are loaded as pattern to form general behavior pattern. The future value is drawn by screening the data references in loaded past pattern. The accuracy of prediction is depend on the analytical method used to predict. Data for the month of January for 7 years are taken as training set.

The training is done by using pattern learning method. The data of previous 7 years are used as inputs. The daily price value is given to the network. The network made used to predict the next value in order.

$\operatorname{MSE}=1 / \mathrm{n}^{\mathrm{n}} \sum_{1=1}\left(\mathrm{y}_{1}-\tilde{\mathrm{y}}_{\mathrm{i}}\right)^{2}$

\section{IMPLEMENTATION OF MULTI-LAYER FEED FORWARD NEURAL NETWORK}

We construct the model which has four inputs (date, open price, high price, low price ) and one output neuron (closing price) and 30 hidden layers of neurons for each. The hidden layer uses the tanH activation function.

The multi-layer networks are formed using the tanH sigmoid function defined in the equation (7). The network described by the knowledge base equation set is shown in the diagram

This diagram explains multi-layer network with three input layers, 30 hidden layers and one output layers.

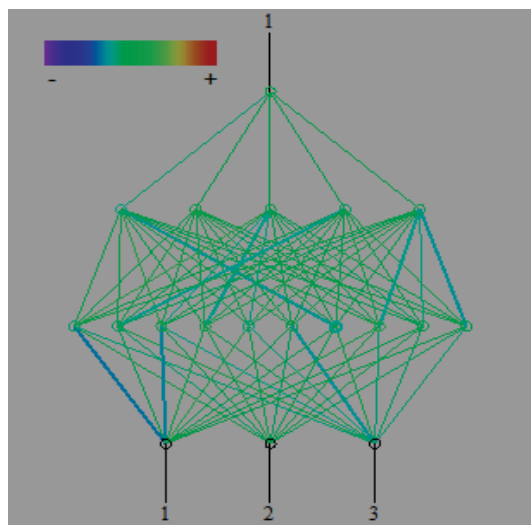

Diagram 5 Multi-layer feed forward network for stock market prediction

Regression line is formed to check the optimality of the network using linear function. This is described in the Diagram 5. The diagram shows the performance plot of the actual and predicted results of the BSE from 2015 to 2018.

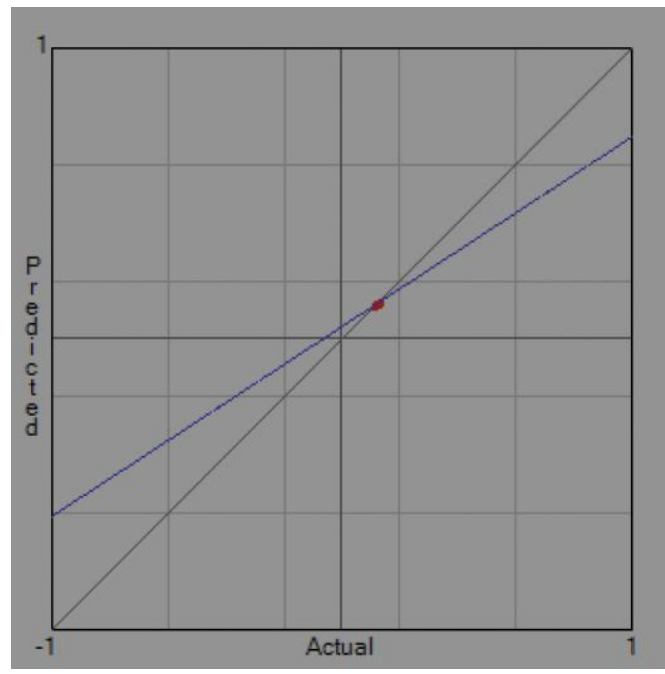

Diagram 6 Performance plot of Multi-layer feed forward stock prediction

\section{OUTPUT}

This section explains the details about the training set and the training set taken from the BSE stock exchange. The training set is taken from the BSE stock exchange from date 2-nov-2015 to 19-Apr-16.Totally 136 data is chosen for testing data.

Table 1 Training data for stock prediction using Multi-layer feed forward network

\begin{tabular}{|c|c|c|c|c|c|c|}
\hline S.no. & Date & Open & High & Low & Close & Volume \\
\hline 1 & 19-Apr-16 & 111.1 & 112.45 & 109.16 & 112.29 & 30147644 \\
\hline 2 & 18-Apr-16 & 109.74 & 110.81 & 109.2 & 110.45 & 21092654 \\
\hline 3 & 15-Apr-16 & 110.79 & 110.97 & 109.2 & 109.64 & 20763396 \\
\hline 4 & 14-Apr-16 & 110.62 & 112.04 & 110.26 & 110.84 & 28430914 \\
\hline 5 & 13-Apr-16 & 112.23 & 112.65 & 106.52 & 110.51 & 88113011 \\
\hline 6 & 12-Apr-16 & 109.34 & 111.16 & 108.99 & 110.61 & 26175943 \\
\hline 7 & 11-Apr-16 & 110.7 & 110.91 & 108.77 & 108.99 & 39563863 \\
\hline 8 & 8-Apr-16 & 114.25 & 114.33 & 109.9 & 110.63 & 48424776 \\
\hline 9 & 7-Apr-16 & 113.79 & 114.89 & 113.07 & 113.64 & 20324759 \\
\hline 10 & 6-Apr-16 & 112.47 & 113.81 & 112.42 & 113.71 & 20522412 \\
\hline
\end{tabular}


Multi Layer Feed Forward Neural Network Knowledge Base to Future Stock Market Prediction

\begin{tabular}{|c|c|c|c|c|c|c|}
\hline 11 & 5-Apr-16 & 112.11 & 113.32 & 111.9 & 112.22 & 22752484 \\
\hline 12 & 4-Apr-16 & 114.07 & 114.55 & 111.61 & 112.55 & 48382180 \\
\hline 13 & 1-Apr-16 & 113.75 & 116.17 & 113.35 & 116.06 & 24725954 \\
\hline 14 & 31-Mar-17 & 114.7 & 115.01 & 113.77 & 114.1 & 21138743 \\
\hline 15 & 30-Mar-16 & 116.73 & 116.99 & 114.36 & 114.7 & 33180317 \\
\hline 16 & 29-Mar-16 & 113.83 & 116.32 & 113.64 & 116.14 & 29765753 \\
\hline 17 & 28-Mar-16 & 113.32 & 114.59 & 112.95 & 113.69 & 21312750 \\
\hline 18 & 24-Mar-16 & 112.13 & 113.09 & 111.68 & 113.05 & 17063766 \\
\hline 19 & 23-Mar-16 & 112.01 & 113.19 & 112 & 112.54 & 18468742 \\
\hline 20 & 22-Mar-16 & 111.36 & 112.88 & 111.17 & 112.25 & 18957831 \\
\hline 21 & 21-Mar-16 & 111.66 & 112.37 & 111.03 & 111.85 & 18394520 \\
\hline 22 & 18-Mar-16 & 111.56 & 112.42 & 110.27 & 111.45 & 36216958 \\
\hline 23 & 17-Mar-16 & 112.15 & 112.69 & 110.73 & 111.02 & 24204773 \\
\hline 24 & 16-Mar-16 & 110.49 & 112.5 & 110.1 & 112.18 & 24619730 \\
\hline 25 & 15-Mar-16 & 109.11 & 110.83 & 108.84 & 110.67 & 17618460 \\
\hline 26 & 14-Mar-16 & 109.28 & 110.33 & 108.77 & 109.89 & 17236054 \\
\hline 27 & 11-Mar-16 & 108.48 & 109.42 & 107.92 & 109.41 & 20581320 \\
\hline 28 & 10-Mar-16 & 107.91 & 108.66 & 105.77 & 107.32 & 24780710 \\
\hline 29 & 9-Mar-16 & 106.7 & 107.51 & 105.49 & 107.51 & 20449881 \\
\hline 30 & 8-Mar-16 & 104.78 & 107.37 & 104.4 & 105.93 & 25493546 \\
\hline 31 & 7-Mar-16 & 108.07 & 108.07 & 104.72 & 105.73 & 31436401 \\
\hline 32 & 4-Mar-16 & 110.05 & 110.05 & 107.93 & 108.39 & 24872895 \\
\hline 33 & 3-Mar-16 & 110.25 & 110.3 & 108.54 & 109.58 & 21333496 \\
\hline 34 & 2-Mar-16 & 109.68 & 110.55 & 108.77 & 109.95 & 25641627 \\
\hline 35 & 1-Mar-16 & 107.83 & 109.82 & 107.6 & 109.82 & 26694696 \\
\hline 36 & 2/29/2017 & 107.6 & 108.91 & 106.75 & 106.92 & 32243645 \\
\hline 37 & 26-Feb-16 & 108.7 & 109.45 & 107.16 & 107.92 & 26578891 \\
\hline
\end{tabular}

\begin{tabular}{|c|c|c|c|c|c|c|}
\hline 38 & 25-Feb-16 & 107.11 & 108.07 & 105.61 & 108.07 & 29796180 \\
\hline 39 & 24-Feb-16 & 104.21 & 106.95 & 102.74 & 106.88 & 34239396 \\
\hline 40 & 23-Feb-16 & 106.85 & 107.47 & 105.12 & 105.46 & 25204873 \\
\hline 41 & 22-Feb-16 & 105.49 & 108.25 & 105.34 & 107.16 & 35630883 \\
\hline 42 & 19-Feb-16 & 102.55 & 105.02 & 102.06 & 104.57 & 32337444 \\
\hline 43 & 18-Feb-16 & 105.8 & 106 & 103.03 & 103.47 & 29374587 \\
\hline 44 & 17-Feb-16 & 101.94 & 105.72 & 100.4 & 105.2 & 43852623 \\
\hline 45 & 16-Feb-16 & 103.8 & 103.93 & 100.24 & 101.61 & 45438324 \\
\hline 46 & 12-Feb-16 & 103.74 & 104.24 & 101.09 & 102.01 & 36038104 \\
\hline 47 & 11-Feb-16 & 99.6 & 105.11 & 98.88 & 101.91 & 43493102 \\
\hline 48 & 10-Feb-16 & 101.55 & 103.25 & 100.24 & 101 & 44943948 \\
\hline 49 & 9-Feb-16 & 97.14 & 102.4 & 96.82 & 99.54 & 62580050 \\
\hline 50 & 8-Feb-16 & 100.41 & 102.68 & 97.46 & 99.75 & 71016537 \\
\hline 51 & 5-Feb-16 & 109.51 & 109.58 & 103.18 & 104.07 & 76522716 \\
\hline 52 & 4-Feb-16 & 111.8 & 111.94 & 109.25 & 110.49 & 38648485 \\
\hline 53 & 3-Feb-16 & 115.27 & 115.34 & 109.75 & 112.69 & 56848084 \\
\hline 54 & 2-Feb-16 & 114.8 & 117.59 & 113.2 & 114.61 & 59644925 \\
\hline 55 & 1-Feb-16 & 112.27 & 115.72 & 112.01 & 115.09 & 45840867 \\
\hline 56 & 29-Jan-17 & 108.99 & 112.84 & 108.84 & 112.21 & 62357459 \\
\hline 57 & 28-Jan-16 & 107.2 & 110.34 & 104.81 & 109.11 & $1.07 \mathrm{E}+08$ \\
\hline 58 & 27-Jan-16 & 97.79 & 97.85 & 94.23 & 94.45 & 48311872 \\
\hline 59 & 26-Jan-16 & 97.76 & 97.88 & 95.66 & 97.34 & 26637412 \\
\hline 60 & 25-Jan-16 & 98.72 & 99.48 & 96.93 & 97.01 & 32319141 \\
\hline 61 & 22-Jan-16 & 96.41 & 98.07 & 95.49 & 97.94 & 30331442 \\
\hline 62 & 21-Jan-16 & 94.91 & 95.99 & 92.62 & 94.16 & 30468830 \\
\hline 63 & 20-Jan-16 & 92.83 & 95 & 89.37 & 94.35 & 58982367 \\
\hline
\end{tabular}


International Journal of Innovative Technology and Exploring Engineering (IJITEE) ISSN: 2278-3075, Volume-8, Issue-11S, September 2019

\begin{tabular}{|c|c|c|c|c|c|c|}
\hline 64 & 19-Jan-16 & 96.53 & 97.42 & 93.92 & 95.26 & 30620565 \\
\hline 65 & 15-Jan-16 & 93.98 & 96.38 & 93.54 & 94.97 & 45935550 \\
\hline 66 & 14-Jan-16 & 95.85 & 98.87 & 92.45 & 98.37 & 48488509 \\
\hline 67 & 13-Jan-16 & 100.58 & 100.58 & 95.21 & 95.44 & 33091576 \\
\hline 68 & 12-Jan-16 & 99 & 99.96 & 97.55 & 99.37 & 28395390 \\
\hline 69 & 11-Jan-16 & 97.91 & 98.6 & 95.39 & 97.51 & 29932385 \\
\hline 70 & 8-Jan-16 & 99.88 & 100.5 & 97.03 & 97.33 & 35402298 \\
\hline 71 & 7-Jan-16 & 100.5 & 101.43 & 97.3 & 97.92 & 45172906 \\
\hline 72 & 6-Jan-16 & 101.13 & 103.77 & 100.9 & 102.97 & 25096183 \\
\hline 73 & 5-Jan-16 & 102.89 & 103.71 & 101.66 & 102.73 & 23258238 \\
\hline 74 & 4-Jan-16 & 101.95 & 102.24 & 99.75 & 102.22 & 37717312 \\
\hline 75 & 31-Dec-17 & 106 & 106.17 & 104.62 & 104.66 & 18391064 \\
\hline 76 & 30-Dec-15 & 107 & 107.25 & 106.06 & 106.22 & 13115007 \\
\hline 77 & 29-Dec-15 & 106.42 & 107.74 & 106.25 & 107.26 & 17179901 \\
\hline 78 & 28-Dec-16 & 105.02 & 105.98 & 104.53 & 105.93 & 13069733 \\
\hline 79 & 24-Dec-15 & 104.74 & 105.32 & 104.5 & 105.02 & 6512134 \\
\hline 80 & 23-Dec-15 & 105.89 & 106.11 & 103.86 & 104.63 & 19599673 \\
\hline 81 & 22-Dec-15 & 105.22 & 105.66 & 104.81 & 105.51 & 14597122 \\
\hline 82 & 21-Dec-15 & 104.91 & 105.15 & 103.6 & 104.77 & 16138786 \\
\hline 83 & 18-Dec-15 & 106.08 & 106.59 & 103.97 & 104.04 & 35994199 \\
\hline 84 & 17-Dec-15 & 107.49 & 107.75 & 106.13 & 106.22 & 21675686 \\
\hline 85 & 16-Dec-15 & 105.37 & 107.09 & 104.19 & 106.79 & 22680547 \\
\hline 86 & 15-Dec-15 & 105.3 & 105.8 & 104.28 & 104.55 & 21764331 \\
\hline 87 & 14-Dec-15 & 102.28 & 104.74 & 101.46 & 104.66 & 24648093 \\
\hline 88 & 11-Dec-15 & 104.15 & 104.34 & 101.91 & 102.12 & 26427727 \\
\hline 89 & 10-Dec-15 & 105.05 & 106.4 & 104.41 & 105.42 & 17454312 \\
\hline 90 & 9-Dec-15 & 106.18 & 106.44 & 103.55 & 104.6 & 23517268 \\
\hline
\end{tabular}

\begin{tabular}{|c|c|c|c|c|c|c|}
\hline 91 & 8-Dec-15 & 104 & 106.91 & 103.95 & 106.49 & 20401791 \\
\hline 92 & 7-Dec-15 & 106.48 & 106.83 & 104.66 & 105.61 & 15474890 \\
\hline 93 & 4-Dec-15 & 104.75 & 107.73 & 104.11 & 106.18 & 21224721 \\
\hline 94 & 3-Dec-15 & 103.95 & 106.85 & 103.35 & 104.38 & 23236485 \\
\hline 95 & 2-Dec-15 & 107 & 107.92 & 105.79 & 106.07 & 24295162 \\
\hline 96 & 1-Dec-15 & 104.83 & 107.15 & 104.5 & 107.12 & 22715616 \\
\hline 97 & 30-Nov-15 & 105.84 & 106.1 & 103.75 & 104.24 & 20008996 \\
\hline 98 & 27-Nov-15 & 105.78 & 105.96 & 104.86 & 105.45 & 5912671 \\
\hline 99 & 25-Nov-15 & 106.33 & 106.6 & 105.1 & 105.41 & 15150785 \\
\hline 100 & 24-Nov-15 & 106 & 106.49 & 104.39 & 105.74 & 23462829 \\
\hline 101 & 23-Nov-15 & 107.19 & 107.47 & 106.08 & 106.95 & 19733283 \\
\hline 102 & 20-Nov-15 & 106.84 & 107.87 & 106.62 & 107.32 & 22085405 \\
\hline 103 & 19-Nov-15 & 107.36 & 107.73 & 105.95 & 106.26 & 25477683 \\
\hline 104 & 18-Nov-15 & 105.8 & 107.88 & 105.39 & 107.77 & 23679764 \\
\hline 105 & 17-Nov-15 & 104.62 & 106.2 & 104.14 & 105.13 & 26649223 \\
\hline 106 & 16-Nov-15 & 103.32 & 104.17 & 100.47 & 104.04 & 49140589 \\
\hline 107 & 13-Nov-15 & 107.71 & 108.25 & 103.83 & 103.95 & 29438853 \\
\hline 108 & 12-Nov-15 & 108.48 & 109.39 & 108 & 108.02 & 20763843 \\
\hline 109 & 11-Nov-15 & 108.27 & 109.87 & 107.11 & 109.01 & 25003046 \\
\hline 110 & 10-Nov-15 & 106.17 & 108.15 & 105.24 & 107.91 & 24409940 \\
\hline 111 & 9-Nov-15 & 107 & 108.25 & 105.86 & 106.49 & 26326885 \\
\hline 112 & 6-Nov-15 & 108.04 & 108.74 & 105.91 & 107.1 & 34898019 \\
\hline 113 & 5-Nov-15 & 108.8 & 110.65 & 107.95 & 108.76 & 63013501 \\
\hline 114 & 4-Nov-15 & 103.19 & 104.14 & 102.48 & 103.94 & 38606400 \\
\hline 115 & 3-Nov-15 & 103.22 & 103.65 & 102.4 & 102.58 & 21096752 \\
\hline 116 & 2-Nov-15 & 101.72 & 103.47 & 101.18 & 103.31 & 23876266 \\
\hline
\end{tabular}

The testing set is taken from date 28-oct-2018 to 20 -apr-2 


\section{Multi Layer Feed Forward Neural Network Knowledge Base to Future Stock Market Prediction}

016. This testing set is defined in Table2. Totally 135 data with open, high, low, close and volumes are taken from the historical data. The $\mathrm{R}$ statistical tool is used to find the predicted value for the closing price and the corresponding error are measured using equation (6). The actual value, predicted value and the errors are displayed in the Table 3. The various stock predictions input historical data from BSE stock exchange with their corresponding plots are described in the following charts from diagram 7 to diagram 11. The plots are describing the values of open, high, low, close and volume. The diagram 12 shows the whole historical data with respect to the corresponding date.

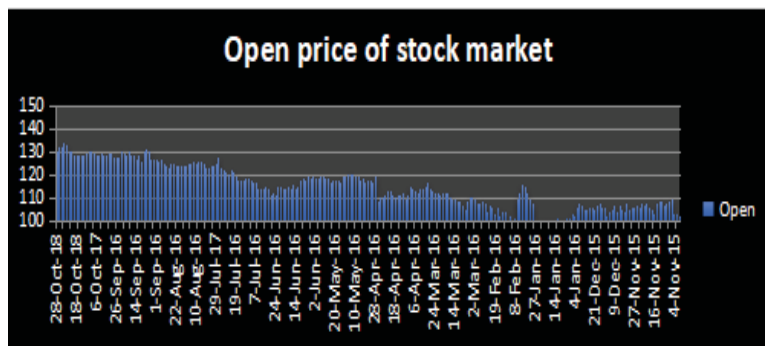

Diagram 7 Open price of stock market

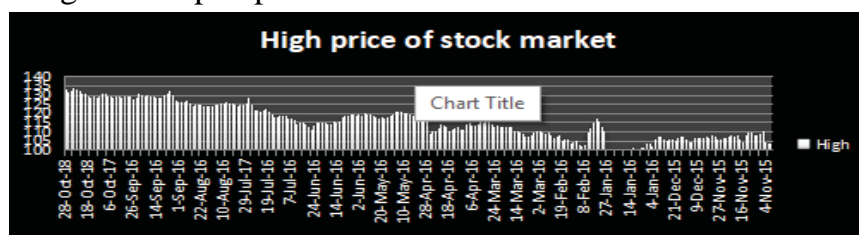

Diagram 8 High price of stock market

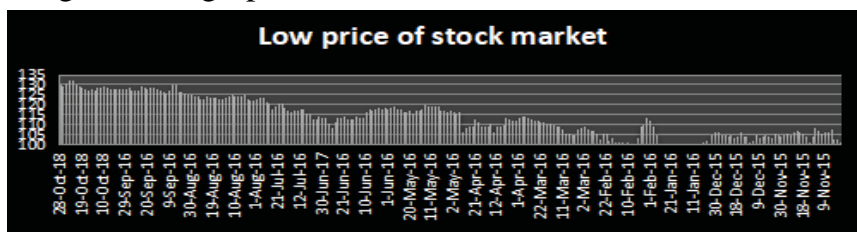

Diagram 9 Low price of stock market

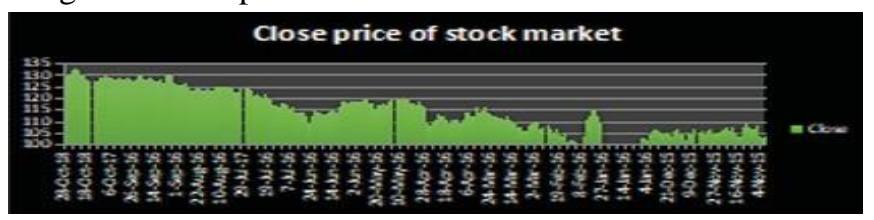

Diagram 10 Close price of stock market

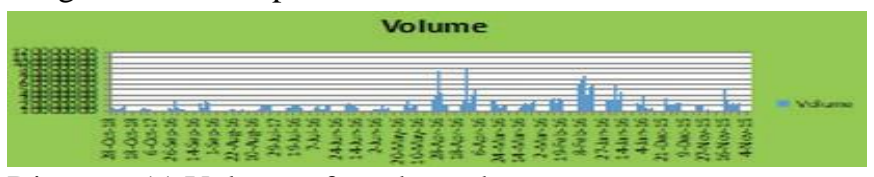

Diagram 11 Volume of stock market

The stock market input layers like open, high and low with the output layer closing price is described by the following performance chart.

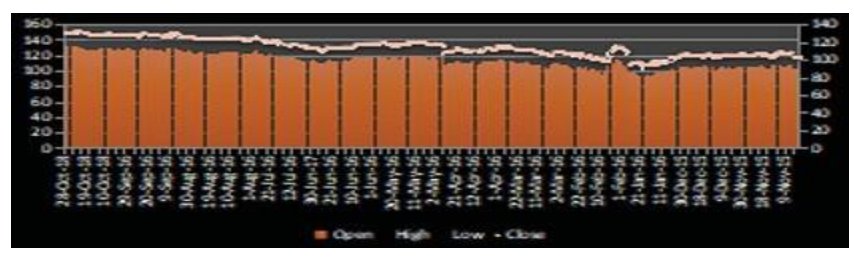

Diagram 12 Volume of stock market
Table 2: Testing data for stock prediction using Multi-layer feed forward network

\begin{tabular}{|c|c|c|c|c|c|c|}
\hline S.no. & Date & Open & High & Low & Close & Volume \\
\hline 1 & $\begin{array}{l}28 \text {-Oct- } 1 \\
8\end{array}$ & 130.5 & 132.97 & 129.93 & 131.29 & 24545547 \\
\hline 2 & $\begin{array}{l}27-\text { Oct- } 1 \\
8\end{array}$ & 131.74 & 131.8 & 129.27 & 129.69 & 16741393 \\
\hline 3 & $\begin{array}{l}26-\text {-Oct- } 1 \\
8\end{array}$ & $131.64 \mathrm{t}$ & 132.26 & 130.94 & 131.04 & 13084731 \\
\hline 4 & $\begin{array}{l}25 \text {-Oct-1 } \\
8\end{array}$ & 133.5 & 133.5 & 132.22 & 132.29 & 13336787 \\
\hline 5 & $\begin{array}{l}24-\text { Oct- } 1 \\
8\end{array}$ & 132.72 & 133.4 & 132.15 & 133.28 & 17470227 \\
\hline 6 & $\begin{array}{l}21 \text {-Oct-1 } \\
8\end{array}$ & 129.78 & 132.13 & 129.7 & 132.07 & 19088794 \\
\hline 7 & $\begin{array}{l}20 \text {-Oct- } 1 \\
8\end{array}$ & 130.07 & 130.66 & 129.5 & 130 & 13167503 \\
\hline 8 & $\begin{array}{l}\text { 19-Oct-1 } \\
8\end{array}$ & 128.74 & 130.47 & 128.6 & 130.11 & 16752321 \\
\hline 9 & $\begin{array}{l}18-O c t-1 \\
8\end{array}$ & 128.68 & 129.39 & 128.01 & 128.57 & 13503967 \\
\hline 10 & $\begin{array}{l}17 \text {-Oct-1 } \\
8\end{array}$ & 128.2 & 128.47 & 127.32 & 127.54 & 11351681 \\
\hline 11 & $\begin{array}{l}14-\text { Oct-1 } \\
8\end{array}$ & 128.49 & 128.95 & 127.58 & 127.88 & 13345292 \\
\hline 12 & $\begin{array}{l}13-\text { Oct-1 } \\
8\end{array}$ & 128.21 & 128.25 & 126.75 & 127.82 & 17139306 \\
\hline 13 & $\begin{array}{l}12-\text { Oct-1 } \\
8\end{array}$ & 129.01 & 129.66 & 128.46 & 129.05 & 11072991 \\
\hline 14 & $\begin{array}{l}11-\text { Oct-1 } \\
8\end{array}$ & 130.23 & 130.64 & 128.23 & 128.88 & 17537928 \\
\hline 15 & $\begin{array}{l}10-\text { Oct-1 } \\
8\end{array}$ & 129.68 & 130.7 & 129.2 & 130.24 & 15138720 \\
\hline 16 & 7-Oct-17 & 129.04 & 129.25 & 128.33 & 128.99 & 12804420 \\
\hline 17 & 6-Oct-17 & 128.43 & 129.06 & 128.08 & 128.74 & 11682729 \\
\hline
\end{tabular}


International Journal of Innovative Technology and Exploring Engineering (IJITEE) ISSN: 2278-3075, Volume-8, Issue-11S, September 2019

\begin{tabular}{|c|c|c|c|c|c|c|}
\hline 18 & 5-Oct-17 & 128.25 & 128.8 & 127.83 & 128.47 & 12386753 \\
\hline 19 & 4-Oct-17 & 129.17 & 129.28 & 127.55 & 128.19 & 14307548 \\
\hline 20 & 3-Oct-17 & 128.38 & 129.09 & 127.8 & 128.77 & 13156943 \\
\hline 21 & $\begin{array}{l}30-\text { Sep-1 } \\
7\end{array}$ & 128.03 & 128.59 & 127.45 & 128.27 & 18402945 \\
\hline 22 & $\begin{array}{l}29-\text { Sep-1 } \\
6\end{array}$ & 129.18 & 129.29 & 127.55 & 128.09 & 14532241 \\
\hline 23 & $\begin{array}{l}28-\text { Sep-1 } \\
6\end{array}$ & 129.21 & 129.47 & 128.4 & 129.23 & 12047636 \\
\hline 24 & $\begin{array}{l}27-\text { Sep-1 } \\
6\end{array}$ & 127.61 & 129.01 & 127.43 & 128.69 & 15637111 \\
\hline 25 & $\begin{array}{l}26-\text { Sep-1 } \\
6\end{array}$ & 127.37 & 128.16 & 126.8 & 127.31 & 15064940 \\
\hline 26 & $\begin{array}{l}23-\text { Sep-1 } \\
6\end{array}$ & 127.56 & 128.6 & 127.3 & 127.96 & 28326266 \\
\hline 27 & $\begin{array}{l}22-\text { Sep-1 } \\
6\end{array}$ & 130.5 & 130.73 & 129.56 & 130.08 & 15538307 \\
\hline 28 & $\begin{array}{l}21-\text { Sep-1 } \\
6\end{array}$ & 129.13 & 130 & 128.39 & 129.94 & 14068336 \\
\hline 29 & $\begin{array}{l}20-\text { Sep-1 } \\
6\end{array}$ & 128.65 & 129.17 & 128.03 & 128.64 & 11083808 \\
\hline 30 & $\begin{array}{l}\text { 19-Sep-1 } \\
6\end{array}$ & 129.91 & 129.94 & 128.26 & 128.65 & 14958794 \\
\hline 31 & $\begin{array}{l}\text { 16-Sep-1 } \\
6\end{array}$ & 128.2 & 129.18 & 128.2 & 129.07 & 24119174 \\
\hline 32 & $\begin{array}{l}\text { 15-Sep-1 } \\
6\end{array}$ & 127.98 & 129.1 & 127.67 & 128.35 & 15111838 \\
\hline 33 & $\begin{array}{l}14-\text { Sep-1 } \\
6\end{array}$ & 126.89 & 128.8 & 126.89 & 127.77 & 15720388 \\
\hline 34 & $\begin{array}{l}\text { 13-Sep-1 } \\
6\end{array}$ & 128.03 & 128.35 & 126.66 & 127.21 & 18016152 \\
\hline 35 & $\begin{array}{l}12-\text { Sep-1 } \\
6\end{array}$ & 125.96 & 128.76 & 125.75 & 128.69 & 21252752 \\
\hline 36 & 9-Sep-16 & 129.71 & 129.95 & 127.1 & 127.1 & 27100679 \\
\hline 37 & 8-Sep-16 & 130.92 & 131.08 & 129.81 & 130.27 & 15676595 \\
\hline
\end{tabular}

\begin{tabular}{|c|c|c|c|c|c|c|}
\hline 38 & 7-Sep-16 & 130.04 & 131.98 & 129.95 & 131.05 & 27990796 \\
\hline 39 & 6-Sep-16 & 126.67 & 129.94 & 126.47 & 129.73 & 26278407 \\
\hline 40 & 2-Sep-16 & 126.85 & 126.86 & 126 & 126.51 & 12118773 \\
\hline 41 & 1-Sep-16 & 126.38 & 126.63 & 125.6 & 126.17 & 13536125 \\
\hline 42 & $\begin{array}{l}\text { 31-Aug- } \\
17\end{array}$ & 125.6 & 126.22 & 125.1 & 126.12 & 14200636 \\
\hline 43 & $\begin{array}{l}\text { 30-Aug- } \\
16\end{array}$ & 126.6 & 126.6 & 125.15 & 125.84 & 17804286 \\
\hline 44 & $\begin{array}{l}\text { 29-Aug- } \\
16\end{array}$ & 124.35 & 126.73 & 124.35 & 126.54 & 15925900 \\
\hline 45 & $\begin{array}{l}26-A u g- \\
16\end{array}$ & 124.05 & 125.19 & 123.91 & 124.96 & 17504825 \\
\hline 46 & $\begin{array}{l}\text { 25-Aug- } \\
16\end{array}$ & 123.12 & 124.37 & 123.1 & 123.89 & 10730811 \\
\hline 47 & $\begin{array}{l}24-A u g- \\
16\end{array}$ & 124.47 & 124.69 & 123.09 & 123.48 & 12243719 \\
\hline 48 & $\begin{array}{l}23 \text {-Aug- } \\
16\end{array}$ & 124.51 & 125.09 & 124.25 & 124.37 & 13309452 \\
\hline 49 & $\begin{array}{l}\text { 22-Aug- } \\
16\end{array}$ & 123.33 & 124.83 & 123.11 & 124.15 & 14386361 \\
\hline 50 & $\begin{array}{l}\text { 19-Aug- } \\
16\end{array}$ & 123.6 & 124.16 & 123.28 & 123.56 & 11688265 \\
\hline 51 & $\begin{array}{l}\text { 18-Aug- } \\
16\end{array}$ & 124.01 & 124.26 & 123.64 & 123.91 & 12400816 \\
\hline 52 & $\begin{array}{l}\text { 17-Aug- } \\
16\end{array}$ & 123.66 & 124.38 & 122.85 & 124.37 & 13794179 \\
\hline 53 & $\begin{array}{l}16 \text {-Aug- } \\
16\end{array}$ & 123.5 & 123.92 & 122.78 & 123.3 & 14222410 \\
\hline 54 & $\begin{array}{l}\text { 15-Aug- } \\
16\end{array}$ & 124.91 & 124.92 & 123.7 & 123.9 & 19295130 \\
\hline 55 & $\begin{array}{l}\text { 12-Aug- } \\
16\end{array}$ & 124.7 & 125 & 124.18 & 124.88 & 12158955 \\
\hline 56 & $\begin{array}{l}\text { 11-Aug- } \\
16\end{array}$ & 125.2 & 125.38 & 124.75 & 124.9 & 11729519 \\
\hline
\end{tabular}


Multi Layer Feed Forward Neural Network Knowledge Base to Future Stock Market Prediction

\begin{tabular}{|c|c|c|c|c|c|c|}
\hline 57 & $\begin{array}{l}\text { 10-Aug- } \\
16\end{array}$ & 125.07 & 125.48 & 124.54 & 124.88 & 10670148 \\
\hline 58 & $\begin{array}{l}\text { 9-Aug-1 } \\
6\end{array}$ & 125.34 & 126.09 & 124.53 & 125.06 & 19620967 \\
\hline 59 & $\begin{array}{l}\text { 8-Aug-1 } \\
6\end{array}$ & 125.25 & 125.45 & 124.55 & 125.26 & 15233929 \\
\hline 60 & $\begin{array}{l}5 \text {-Aug-1 } \\
6\end{array}$ & 124.98 & 125.84 & 124.62 & 125.15 & 20184035 \\
\hline 61 & $\begin{array}{l}\text { 4-Aug-1 } \\
6\end{array}$ & 122.94 & 124.79 & 122.51 & 124.36 & 21065974 \\
\hline 62 & $\begin{array}{l}\text { 3-Aug-1 } \\
6\end{array}$ & 123.09 & 123.92 & 122.31 & 122.51 & 18525332 \\
\hline 63 & $\begin{array}{l}\text { 2-Aug-1 } \\
6\end{array}$ & 124.06 & 124.8 & 122.07 & 123.09 & 23968414 \\
\hline 64 & $\begin{array}{l}\text { 1-Aug-1 } \\
6\end{array}$ & 123.85 & 124.58 & 122.86 & 124.31 & 25006850 \\
\hline 65 & $\begin{array}{l}\text { 29-Jul-1 } \\
7\end{array}$ & 124.65 & 125.84 & 123.71 & 123.94 & 35058803 \\
\hline 66 & $\begin{array}{l}\text { 28-Jul-1 } \\
6\end{array}$ & 127.52 & 128.33 & 123.63 & 125 & 78955758 \\
\hline 67 & $\begin{array}{l}\text { 27-Jul-1 } \\
6\end{array}$ & 122.42 & 125 & 121.51 & 123.34 & 52654239 \\
\hline 68 & $\begin{array}{l}\text { 26-Jul-1 } \\
6\end{array}$ & 122 & 122.07 & 120.75 & 121.22 & 17611964 \\
\hline 69 & $\begin{array}{l}25-J u l-1 \\
6\end{array}$ & 121.39 & 121.85 & 117.78 & 121.63 & 18487449 \\
\hline 70 & $\begin{array}{l}\text { 22-Jul-1 } \\
6\end{array}$ & 119.9 & 121.01 & 119.31 & 121 & 18422410 \\
\hline 71 & $\begin{array}{l}\text { 21-Jul-1 } \\
6\end{array}$ & 121.92 & 122.1 & 120.25 & 120.61 & 17801663 \\
\hline 72 & $\begin{array}{l}20-J u l-1 \\
6\end{array}$ & 121.25 & 122.2 & 120.56 & 121.92 & 20046452 \\
\hline 73 & $\begin{array}{l}\text { 19-Jul-1 } \\
6\end{array}$ & 118.99 & 120.85 & 118.66 & 120.61 & 21541292 \\
\hline 74 & $\begin{array}{l}\text { 18-Jul-1 } \\
6\end{array}$ & 117.32 & 119.61 & 116.89 & 119.37 & 20868367 \\
\hline 75 & 15-Jul-1 & 117.74 & 118.28 & 116.58 & 116.86 & 16645964 \\
\hline
\end{tabular}

\begin{tabular}{|c|c|c|c|c|c|c|}
\hline & 6 & & & & & \\
\hline 76 & $\begin{array}{l}\text { 14-Jul-1 } \\
6\end{array}$ & 117.5 & 117.64 & 116.7 & 117.29 & 14579736 \\
\hline 77 & $\begin{array}{l}\text { 13-Jul-1 } \\
6\end{array}$ & 118.39 & 118.4 & 116.68 & 116.78 & 16207662 \\
\hline 78 & $\begin{array}{l}\text { 12-Jul-1 } \\
6\end{array}$ & 118.63 & 118.72 & 117.57 & 117.93 & 15217700 \\
\hline 79 & $\begin{array}{l}11-J u l-1 \\
6\end{array}$ & 117.71 & 118.7 & 117.5 & 117.87 & 17711570 \\
\hline 80 & 8-Jul-16 & 116.43 & 117.5 & 115.85 & 117.24 & 18142597 \\
\hline 81 & 7-Jul-16 & 116.63 & 116.97 & 115.36 & 115.85 & 16630201 \\
\hline 82 & 6-Jul-16 & 113.36 & 116.79 & 112.97 & 116.7 & 24337586 \\
\hline 83 & 5-Jul-16 & 113.94 & 114.11 & 112.97 & 114 & 14207037 \\
\hline 84 & 1-Jul-16 & 114.2 & 115.13 & 113.81 & 114.19 & 14980023 \\
\hline 85 & $\begin{array}{l}\text { 30-Jun-1 } \\
7\end{array}$ & 114.67 & 115.18 & 113.67 & 114.28 & 23192716 \\
\hline 86 & $\begin{array}{l}\text { 29-Jun-1 } \\
6\end{array}$ & 113.37 & 114.25 & 113.04 & 114.16 & 20968273 \\
\hline 87 & $\begin{array}{l}28 \text {-Jun-1 } \\
6\end{array}$ & 110.63 & 112.75 & 110.55 & 112.7 & 26813842 \\
\hline 88 & $\begin{array}{l}\text { 27-Jun-1 } \\
6\end{array}$ & 111.57 & 111.57 & 108.23 & 108.97 & 36409606 \\
\hline 89 & $\begin{array}{l}\text { 24-Jun-1 } \\
6\end{array}$ & 111.01 & 113.68 & 111 & 112.08 & 40643130 \\
\hline 90 & $\begin{array}{l}\text { 23-Jun-1 } \\
6\end{array}$ & 114.37 & 115.09 & 113.54 & 115.08 & 16176895 \\
\hline 91 & $\begin{array}{l}\text { 22-Jun-1 } \\
6\end{array}$ & 114.65 & 114.74 & 113.61 & 113.91 & 14846329 \\
\hline 92 & $\begin{array}{l}\text { 21-Jun-1 } \\
6\end{array}$ & 114.12 & 115.21 & 113.97 & 114.38 & 19166269 \\
\hline 93 & $\begin{array}{l}20-\text { Jun-1 } \\
6\end{array}$ & 113.77 & 114.72 & 112.75 & 113.37 & 20785390 \\
\hline
\end{tabular}


International Journal of Innovative Technology and Exploring Engineering (IJITEE) ISSN: 2278-3075, Volume-8, Issue-11S, September 2019

\begin{tabular}{|c|c|c|c|c|c|c|}
\hline 94 & $\begin{array}{l}\text { 17-Jun-1 } \\
6\end{array}$ & 114.42 & 114.43 & 112.56 & 113.02 & 24644308 \\
\hline 95 & $\begin{array}{l}16-J u n-1 \\
6\end{array}$ & 113.87 & 114.5 & 112.94 & 114.39 & $\begin{array}{l}19236255 \\
7\end{array}$ \\
\hline 98 & $\begin{array}{l}\text { 13-Jun-1 } \\
6\end{array}$ & 115 & 115.48 & 113.31 & 113.95 & 31718239 \\
\hline 99 & $\begin{array}{l}\text { 10-Jun-1 } \\
6\end{array}$ & 117.54 & 118.11 & 116.26 & 116.62 & 18510826 \\
\hline 100 & 9-Jun-16 & 118.13 & 118.68 & 117.71 & 118.56 & 13859240 \\
\hline 101 & 8-Jun-16 & 117.76 & 118.6 & 117.27 & 118.39 & 14505596 \\
\hline 102 & 7-Jun-16 & 119.24 & 119.3 & 117.67 & 117.76 & 17103023 \\
\hline 103 & 6-Jun-16 & 118.62 & 119.43 & 118.36 & 118.79 & 12744676 \\
\hline 104 & 3-Jun-16 & 118.98 & 118.98 & 117.86 & 118.47 & 14135114 \\
\hline 105 & 2-Jun-16 & 118.69 & 119.44 & 118.22 & 118.93 & 13228310 \\
\hline 106 & 1-Jun-16 & 118.5 & 119.08 & 117.82 & 118.78 & 15029494 \\
\hline 107 & $\begin{array}{l}\text { 31-May- } \\
17\end{array}$ & 119.46 & 120.1 & 118.12 & 118.81 & 23547597 \\
\hline 108 & $\begin{array}{l}\text { 27-May- } \\
16\end{array}$ & 119.56 & 119.85 & 119.01 & 119.38 & 13464434 \\
\hline 109 & $\begin{array}{l}\text { 26-May- } \\
16\end{array}$ & 118.24 & 119.76 & 117.92 & 119.47 & 18191472 \\
\hline 110 & $\begin{array}{l}\text { 25-May- } \\
16\end{array}$ & 118.13 & 118.66 & 117.38 & 117.89 & 20019778 \\
\hline 111 & $\begin{array}{l}\text { 24-May- } \\
16\end{array}$ & 116.24 & 117.73 & 116.12 & 117.7 & 20074093 \\
\hline 112 & $\begin{array}{l}\text { 23-May- } \\
16\end{array}$ & 117.42 & 117.6 & 115.94 & 115.97 & 20367390 \\
\hline 113 & $\begin{array}{l}\text { 20-May- } \\
16\end{array}$ & 116.96 & 117.99 & 116.95 & 117.35 & 18870608 \\
\hline 114 & $\begin{array}{l}\text { 19-May- } \\
16\end{array}$ & 117.05 & 117.49 & 115.88 & 116.81 & 20485379 \\
\hline 115 & $\begin{array}{l}\text { 18-May- } \\
16\end{array}$ & 116.8 & 118.27 & 116.73 & 117.65 & 21571824 \\
\hline 116 & 17-May- & 118.82 & 119.01 & 117.2 & 117.35 & 21269720 \\
\hline
\end{tabular}

\begin{tabular}{|c|c|c|c|c|c|c|}
\hline & 16 & & & & & \\
\hline 117 & $\begin{array}{l}\text { 16-May- } \\
16\end{array}$ & 119.38 & 119.61 & 117.35 & 118.67 & 31178289 \\
\hline 118 & $\begin{array}{l}\text { 13-May- } \\
16\end{array}$ & 120.38 & 120.64 & 119.68 & 119.81 & 18047101 \\
\hline 119 & $\begin{array}{l}\text { 12-May- } \\
16\end{array}$ & 119.98 & 120.84 & 118.9 & 120.28 & 21636556 \\
\hline 120 & $\begin{array}{l}\text { 11-May- } \\
16\end{array}$ & 120.41 & 121.08 & 119.42 & 119.52 & 21927392 \\
\hline 121 & $\begin{array}{l}\text { 10-May- } \\
16\end{array}$ & 119.62 & 120.5 & 119 & 120.5 & 22803690 \\
\hline 122 & $\begin{array}{l}\text { 9-May-1 } \\
6\end{array}$ & 119.54 & 120.28 & 118.9 & 119.24 & 21077084 \\
\hline 123 & $\begin{array}{l}\text { 6-May-1 } \\
6\end{array}$ & 117.16 & 119.64 & 117.11 & 119.49 & 26216236 \\
\hline 124 & $\begin{array}{l}\text { 5-May-1 } \\
6\end{array}$ & 118.04 & 118.98 & 117.25 & 117.81 & 21999237 \\
\hline 125 & $\begin{array}{l}\text { 4-May-1 } \\
6\end{array}$ & 116.61 & 118.3 & 116.57 & 118.06 & 23380209 \\
\hline 126 & $\begin{array}{l}\text { 3-May-1 } \\
6\end{array}$ & 117.52 & 118.16 & 117.02 & 117.43 & 23746203 \\
\hline 127 & $\begin{array}{l}\text { 2-May-1 } \\
6\end{array}$ & 117.83 & 118.73 & 116.57 & 118.57 & 27769280 \\
\hline 128 & $\begin{array}{l}\text { 29-Apr-1 } \\
7\end{array}$ & 116.82 & 117.84 & 115.84 & 117.58 & 37031156 \\
\hline 129 & $\begin{array}{l}28 \text {-Apr-1 } \\
6\end{array}$ & 119.58 & 120.79 & 116.23 & 116.73 & 86746016 \\
\hline 130 & $\begin{array}{l}27-A p r-1 \\
6\end{array}$ & 107.94 & 108.94 & 106.31 & 108.89 & 44036820 \\
\hline 131 & $\begin{array}{l}26-A p r-1 \\
6\end{array}$ & 110.49 & 110.5 & 108.15 & 108.76 & 22189916 \\
\hline 132 & $\begin{array}{l}25-A p r-1 \\
6\end{array}$ & 109.87 & 110.67 & 109.07 & 110.1 & 20979671 \\
\hline 133 & $\begin{array}{l}22-A p r-1 \\
6\end{array}$ & 111.21 & 111.75 & 109.01 & 110.56 & 38330597 \\
\hline
\end{tabular}


Multi Layer Feed Forward Neural Network Knowledge Base to Future Stock Market Prediction

\begin{tabular}{|l|l|l|l|l|l|l|}
\hline 134 & $\begin{array}{l}21 \text {-Apr-1 } \\
6\end{array}$ & 112.55 & 114.04 & 112.31 & 113.44 & 20409388 \\
\hline 135 & $\begin{array}{l}20 \text {-Apr-1 } \\
6\end{array}$ & 112.43 & 113.27 & 111.56 & 112.42 & 20998319 \\
\hline
\end{tabular}

The following Table 3 shows the actual and predicted closing price of the stock with error values. All these values are calculated by using equations (2) to (6). The results are listed in the table 3. The performance chart plots of the actual and predicted values are shown in the following diagrams

Table 3 Performance report of actual and predicted closing price by multi-layer feed forward neural network

\begin{tabular}{|c|c|c|c|c|c|c|c|c|}
\hline \multirow[t]{2}{*}{ no.s } & \multirow[t]{2}{*}{ date } & \multicolumn{3}{|c|}{ three input layers } & \multicolumn{4}{|c|}{ output layer with error rate } \\
\hline & & open price & high price & low price & $\begin{array}{c}\text { actual } \\
\text { closing } \\
\text { price }\end{array}$ & $\begin{array}{c}\text { predicted } \\
\text { closing } \\
\text { price }\end{array}$ & $\begin{array}{c}\text { error } \\
\text { rate }\end{array}$ & $\begin{array}{c}\text { error rate } \\
\%\end{array}$ \\
\hline 1 & \begin{tabular}{|l|}
28 -Oct-1 \\
8
\end{tabular} & 0.10916 & 0.1144171 & 0.1144171 & 112.29 & 114.4171 & 2.1271 & 0.021271 \\
\hline 2 & \begin{tabular}{|l|}
27 -Oct-1 \\
8
\end{tabular} & 0.1092 & 0.1139759 & 0.1139759 & 110.45 & 113.9759 & 3.5259 & 0.035259 \\
\hline 3 & \begin{tabular}{|l|}
26 -Oct-1 \\
8
\end{tabular} & 0.1092 & 0.1143268 & 0.1143268 & 109.64 & 114.3268 & 4.6868 & 0.046868 \\
\hline 4 & \begin{tabular}{|l|}
25 -Oct-1 \\
8
\end{tabular} & 0.11026 & 0.1146218 & 0.1146218 & 110.84 & 114.6218 & 3.7818 & 0.037818 \\
\hline 5 & \begin{tabular}{|l|}
$24-O c t-1$ \\
8
\end{tabular} & 0.10652 & 0.1139179 & 0.1139179 & 110.51 & 113.9179 & 3.4079 & 0.034079 \\
\hline 6 & \begin{tabular}{|l|}
$21-O c t-1$ \\
8
\end{tabular} & 0.10899 & 0.1137725 & 0.1137725 & 110.61 & 113.7725 & 3.1625 & 0.031625 \\
\hline 7 & \begin{tabular}{|l|}
20 -Oct-1 \\
8
\end{tabular} & 0.10877 & 0.114154 & 0.114154 & 108.99 & 114.154 & 5.164 & 0.05164 \\
\hline 8 & $\begin{array}{l}19 \text {-Oct-1 } \\
8\end{array}$ & 0.1099 & 0.1157142 & 0.1157142 & 110.63 & 115.7142 & 5.0842 & 0.050842 \\
\hline 9 & $\begin{array}{l}18 \text {-Oct- } 1 \\
8\end{array}$ & 0.11307 & 0.1166116 & 0.1166116 & 113.64 & 116.6116 & 2.9716 & 0.029716 \\
\hline 10 & \begin{tabular}{|l}
17 -Oct- 1 \\
8
\end{tabular} & 0.11242 & 0.1159558 & 0.1159558 & 113.71 & 115.9558 & 2.2458 & 0.022458 \\
\hline 11 & \begin{tabular}{|l|}
$14-O c t-1$ \\
8
\end{tabular} & 0.1119 & 0.1156632 & 0.1156632 & 112.22 & 115.6632 & 3.4432 & 0.034432 \\
\hline 12 & \begin{tabular}{|l|}
13 -Oct-1 \\
8
\end{tabular} & 0.11161 & 0.1162211 & 0.1162211 & 112.55 & 116.2211 & 3.6711 & 0.036711 \\
\hline 13 & \begin{tabular}{|l|}
12 -Oct-1 \\
8
\end{tabular} & 0.11335 & 0.116691 & 0.116691 & 116.06 & 116.691 & 0.631 & 0.00631 \\
\hline 14 & $\begin{array}{l}11 \text {-Oct-1 } \\
8\end{array}$ & 0.11377 & 0.1171469 & 0.1171469 & 114.1 & 117.1469 & 3.0469 & 0.030469 \\
\hline 15 & $\begin{array}{l}10-\text { Oct-1 } \\
8\end{array}$ & 0.11436 & 0.1180187 & 0.1180187 & 114.7 & 118.0187 & 3.3187 & 0.033187 \\
\hline 16 & 7-Oct-17 & 0.11364 & 0.1168137 & 0.1168137 & 116.14 & 116.8137 & 0.6737 & 0.006737 \\
\hline
\end{tabular}




\begin{tabular}{|c|c|c|c|c|c|c|c|c|}
\hline 44 & \begin{tabular}{|l|}
29 -Aug- \\
16
\end{tabular} & 0.1004 & 0.1084367 & 0.1084367 & 105.2 & 108.4367 & 3.2367 & \begin{tabular}{|l|}
0.032367 \\
\end{tabular} \\
\hline 45 & \begin{tabular}{|l|}
26 -Aug- \\
16
\end{tabular} & 0.10024 & 0.1090073 & 0.1090073 & 101.61 & 109.0073 & 7.3973 & 0.073973 \\
\hline 46 & \begin{tabular}{|l|}
25 -Aug- \\
16
\end{tabular} & 0.10109 & 0.1092704 & 0.1092704 & 102.01 & 109.2704 & 7.2604 & 0.072604 \\
\hline 47 & \begin{tabular}{|l|}
$24-A u g-$ \\
16
\end{tabular} & 0.09888 & 0.1071445 & 0.1071445 & 101.91 & 107.1445 & 5.2345 & 0.052345 \\
\hline 48 & \begin{tabular}{|l|}
23 -Aug- \\
16
\end{tabular} & 0.10024 & 0.1082525 & 0.1082525 & 101 & 108.2525 & 7.2525 & 0.072525 \\
\hline 49 & \begin{tabular}{|l|}
22 -Aug- \\
16
\end{tabular} & 0.09682 & 0.1056305 & 0.1056305 & 99.54 & 105.6305 & 6.0905 & 0.060905 \\
\hline 50 & \begin{tabular}{|l|} 
19-Aug- \\
16
\end{tabular} & 0.09746 & 0.1069429 & 0.1069429 & 99.75 & 106.9429 & 7.1929 & 0.071929 \\
\hline 51 & \begin{tabular}{|l|}
18 -Aug- \\
16
\end{tabular} & 0.10318 & 0.1118985 & 0.1118985 & 104.07 & 111.8985 & 7.8285 & 0.078285 \\
\hline 52 & \begin{tabular}{|l|}
17 -Aug- \\
16
\end{tabular} & 0.10925 & 0.1146808 & 0.1146808 & 110.49 & 114.6808 & 4.1908 & 0.041908 \\
\hline 53 & \begin{tabular}{|l|}
16 -Aug- \\
16
\end{tabular} & 0.10975 & 0.1160046 & 0.1160046 & 112.69 & 116.0046 & 3.3146 & 0.033146 \\
\hline 54 & \begin{tabular}{|l|} 
15-Aug-Aug \\
16
\end{tabular} & 0.1132 & 0.1169914 & 0.1169914 & 114.61 & 116.9914 & 2.3814 & 0.023814 \\
\hline 55 & \begin{tabular}{|l|} 
12-Aug- \\
16
\end{tabular} & 0.11201 & 0.1157531 & 0.1157531 & 115.09 & 115.7531 & 0.6631 & 0.006631 \\
\hline 56 & \begin{tabular}{|l|}
11 -Aug- \\
16
\end{tabular} & 0.10884 & 0.1136057 & 0.1136057 & 112.21 & 113.6057 & 1.3957 & 0.013957 \\
\hline 57 & \begin{tabular}{|l|}
10 -Aug- \\
16
\end{tabular} & 0.10481 & 0.1116677 & 0.1116677 & 109.11 & 111.6677 & 2.5577 & 0.025577 \\
\hline 58 & \begin{tabular}{|l|} 
9-Aug-1 \\
6
\end{tabular} & 0.09423 & 0.1049844 & 0.1049844 & 94.45 & 104.9844 & $\begin{array}{l}10.534 \\
4\end{array}$ & \begin{tabular}{|l|}
0.105344 \\
\end{tabular} \\
\hline 59 & \begin{tabular}{|l|} 
8-Aug-1 \\
6
\end{tabular} & 0.09566 & 0.1054518 & 0.1054518 & 97.34 & 105.4518 & 8.1118 & 0.081118 \\
\hline 60 & \begin{tabular}{|l|}
5 -Aug- 1 \\
6
\end{tabular} & 0.09693 & 0.1061983 & 0.1061983 & 97.01 & 106.1983 & 9.1883 & \begin{tabular}{|l|}
0.091883 \\
\end{tabular} \\
\hline 61 & \begin{tabular}{|l|} 
4-Aug-1 \\
6
\end{tabular} & 0.09549 & 0.1049411 & 0.1049411 & 97.94 & 104.9411 & 7.0011 & \begin{tabular}{|l|}
0.070011 \\
\end{tabular} \\
\hline 62 & \begin{tabular}{|l|} 
3-Aug-1 \\
6
\end{tabular} & 0.09262 & 0.1034776 & 0.1034776 & 94.16 & 103.4776 & 9.3176 & $\mid 0.093176$ \\
\hline 63 & \begin{tabular}{|l|}
2 -Aug- 1 \\
6
\end{tabular} & 0.08937 & 0.1016904 & \begin{tabular}{|l|l|}
0.1016904 \\
\end{tabular} & 94.35 & 101.6904 & 7.3404 & 0.073404 \\
\hline 64 & \begin{tabular}{|l|} 
1-Aug-1 \\
6
\end{tabular} & 0.09392 & 0.1044571 & 0.1044571 & 95.26 & 104.4571 & 9.1971 & 0.091971 \\
\hline 65 & \begin{tabular}{|l|} 
29-Jul-1 \\
7
\end{tabular} & 0.09354 & 0.103472 & 0.103472 & 94.97 & \begin{tabular}{|l|}
103.472 \\
\end{tabular} & 8.502 & 0.08502 \\
\hline 66 & \begin{tabular}{|l|}
$28-J u l-1$ \\
6
\end{tabular} & 0.09245 & 0.1037371 & 0.1037371 & 98.37 & 103.7371 & 5.3671 & 0.053671 \\
\hline 67 & \begin{tabular}{|l|}
$27-J u l-1$ \\
6
\end{tabular} & 0.09521 & 0.1062492 & 0.1062492 & 95.44 & 106.2492 & $\begin{array}{l}10.809 \\
25\end{array}$ & 0.108092 \\
\hline 68 & \begin{tabular}{|l|}
$26-J u l-1$ \\
6
\end{tabular} & 0.09755 & 0.1064993 & 0.1064993 & 99.37 & 106.4993 & 7.1293 & 0.071293 \\
\hline 69 & 25-Jul-1 & 0.09539 & 0.1054121 & 0.1054121 & 97.51 & 105.4121 & 7.9021 & \begin{tabular}{|l|}
0.079021 \\
\end{tabular} \\
\hline
\end{tabular}

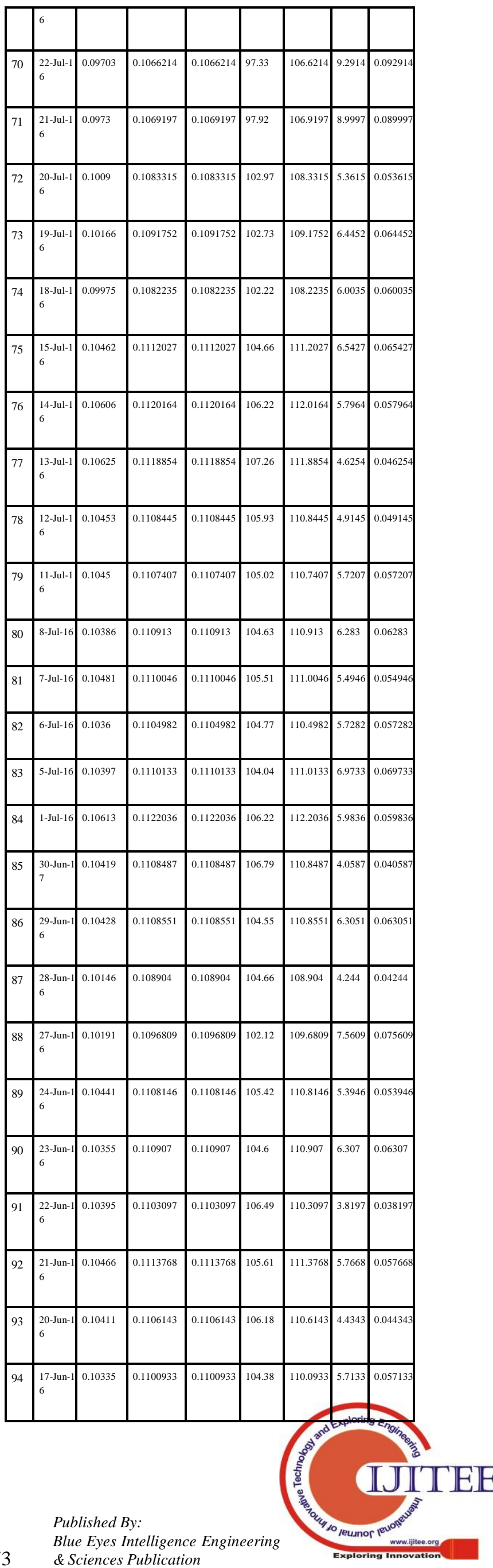




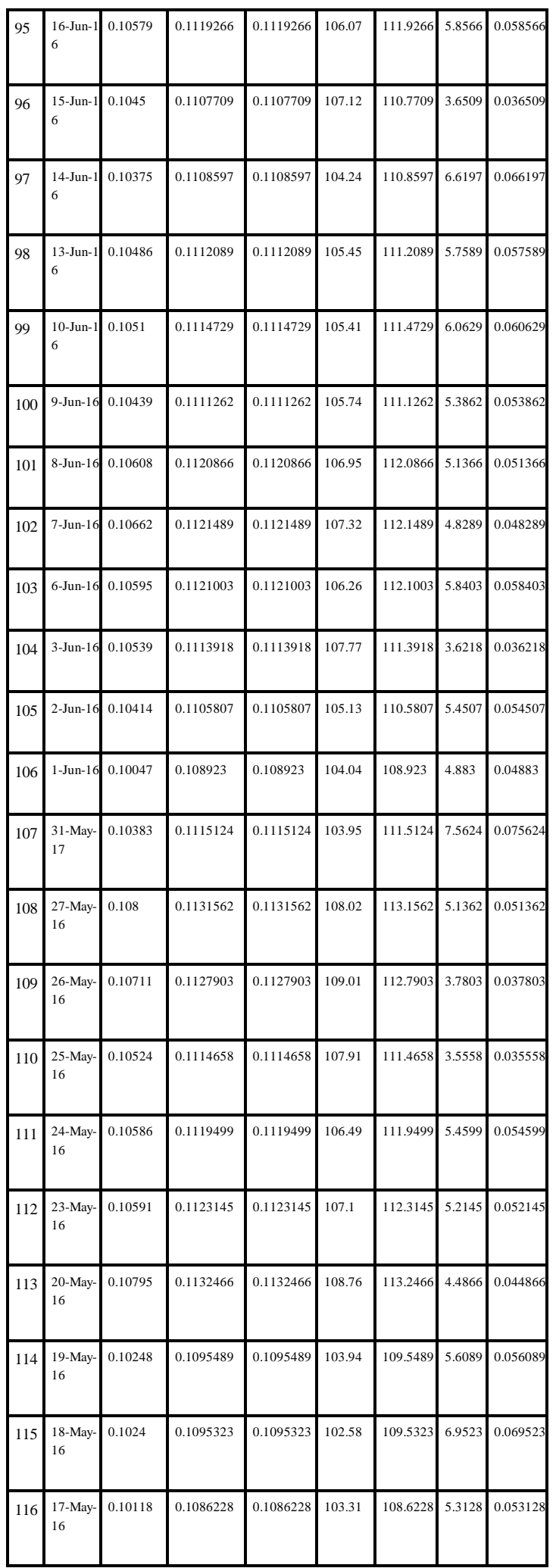

The performance plot using the multi-layer feed forward neural network with linear actual and predicted results are plotted in the following diagram 13.

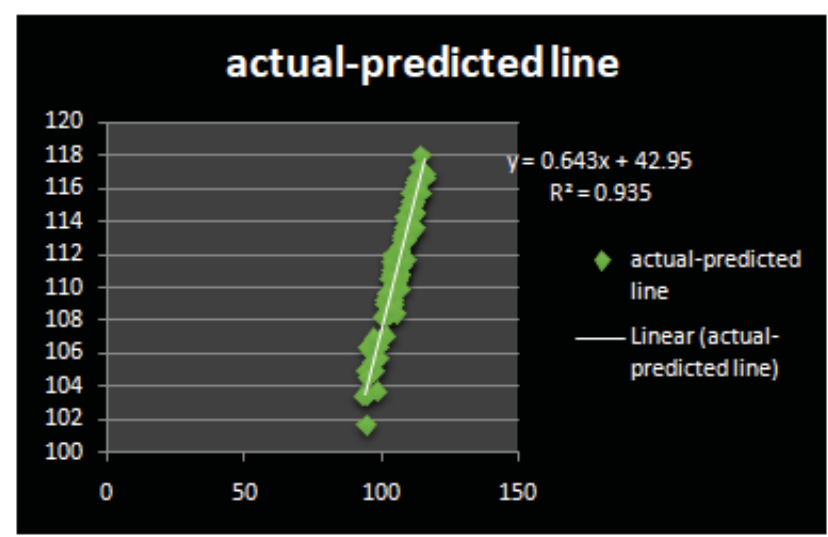

Diagram 13: A performance plot of actual and predicted closing stock market price

The performance analysis of the predicted and error rate is described in the diagram 14. The lerning method used here is the linear line classifier.

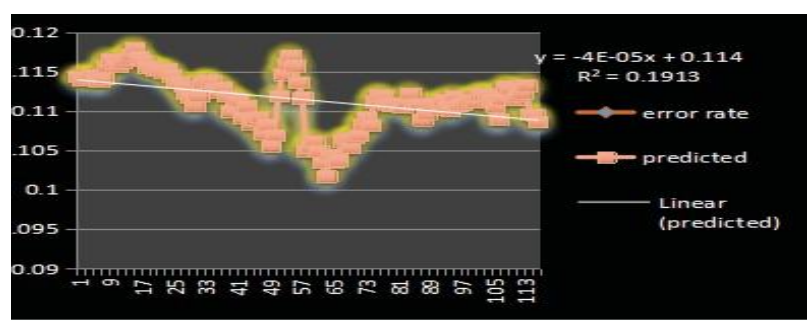

Diagram 14: A performance plot of predicted and error rate of closing price stock market

\section{RESULT AND CONCLUSION}

Future stock prediction is necessary for the gaining profit using the stocks. In this paper the output layer closing price is calculated by using input layer like open price, high price and low price. The mean absolute error value is calculated as the performance measure. The prediction was based on by considering the BSE stock market exchange. The actual and predicted values for the closing price are listed in the table 4. This table describes the error rates which show only minimum change with the actual and predicted results. The performance measures are plotted in the graph by using tanH activation function and linear classifier. This paper results that multi-layer feed forward neural network method results significances change in future stock prediction.

\section{REFERENCES}

1. Sachin Kamley, Shailesh Jaloree and R. S. Thakur, "Multiple regression : a data mining approach for predicting the stock market trends based on open, close and high price of the month", Vol. 3, Issue 4, Oct 2013.

2. S Abdulsalam Sulaiman Olaniyi, Adewole, Kayode S. and Jimoh, R. G "Stock Trend Prediction Using Regression Analysis - A Data Mining Approach" Volume 1 No. 4, JULY 2011

3. Mayankkumar B Patel and Sunil R Yalamalle. "Stock Price Prediction Using Artificial Neural Network “ June2014

4. Adebiyi Ayodele A., Ayo Charles K, Adebiyi Marion O, Otokiti Sunday and O. Stock Price "Prediction using Neural Network with Hybridized Market Indicators” JANUARY 2012 
5. Clive W.J. G-anger S, "Forecasting stock market prices Lessons for forecasters", 1992.

6. Paul D. Yoo , Maria H. Kim , and Tony Jan, "Machine learning techniques and use of event information for stock market prediction A survey and evaluation" YEAR 2005

7. Abubakar S. Magaji, Victor Onomza Waziri, Audu Isah, Adeboye K.R "A Generic Prediction of Nigeria Stock Exchange Market, Implementation Using Naive Bayes Model".

8. Rajesh V. Argiddi , Dr.Mrs.S.S.Apte , Bhagyashri and U. Kale "An Analysis on Stock Market Intelligence and Research Approaches" JAN 2014.

9. "Stock Market Index Prediction by Hybrid NeuroGenetic Data Mining Technique"

10. Ganesh V. Kumbhar, Rajesh and V. Argiddi "Stock Market Index Prediction by Hybrid NeuroGenetic Data Mining Technique".

11. Rupinder kaur and Ms. Vidhu Kiran, "Efficient Artificial Neura Network based Practical Approach of Stock Market Forecasting”, AUGUST 2015.

12. Dharamveer Sisodia, Beerendra Kumar and Jitendra Kumar Gupta "Efficient Prediction of Close Value using Genetic algorithm based horizontal partition decision tree in Stock Market" JANUARY 2014.

13. G.S.navale, nishant uddhwala, kunal jadhav, pawan gabda and brij kishor vihangam, "Prediction of Stock Market using Data Mining and Artificial Intelligence", JANUARY 2016

14. Binoy B. Nair, V.P Mohandas and N.R. Sakthivel "A Genetic Algorithm Optimized Decision TreeSVM based Stock Market Trend Prediction System", 2010.

15. Sneha Soni "Applications of ANNs in Stock Market Prediction: A Survey"

16. Bhagwant Chauhan, Umesh Bidave, Ajit Gangathade and Sachin Ka, "Stock Market Prediction Using Artificial Neural Networks"2014.

17. S Abdulsalam Sulaiman Olaniyi, Adewole, Kayode S, and Jimoh, R. G "Stock Trend Prediction Using Regression Analysis - A Data Mining Approach" JULY 2011.

18. Zahid Iqbal, R. Ilyas, W. Shahzad, Z. Mahmood and J. Anjum, "Efficient Machine Learning Techniques for Stock Market Prediction" NOV-DEC 2013

19. Sayali Metkar, Akash Bhagyawant and Vrushali Bagul ““'Stock Market Prediction and Automation of Sale Purchase Event using History Analysis."SEPTEMBER 2013

20. Dr.P.Karthikeyan and G.Thamizhendhi, "Forecasting Stock Market predictions using Artificial Neural Network Models: A Survey" JULY 2016.

21. Prof.Sarita Sapka1,Tejashree Barate, Neelam Kadbne, Mayuri Pimple and Pallavi Kumbharka, Comparative Study and Analysis of Stock Market Prediction Algorithms " MARCH 2016.

22. A. NagaBhushana Rao and K. Eswara Rao, "Estimize Bull speed using Back propagation"

23. Farhad Soleimanian Gharehchopogh, Tahmineh Haddadi Bonab and Seyyed Reza Khaze "Linear regression approach to predictionof stock market trading volume: a case study “

24. Varunesh Nichante and Prof. Sulabha Patil, "A Review: Analysis of stock market by using big data analytic technology"

25. Selvan Simon and Arun Raoot "Accuracy driven artificial neural networks in stock market prediction" May 2012. 